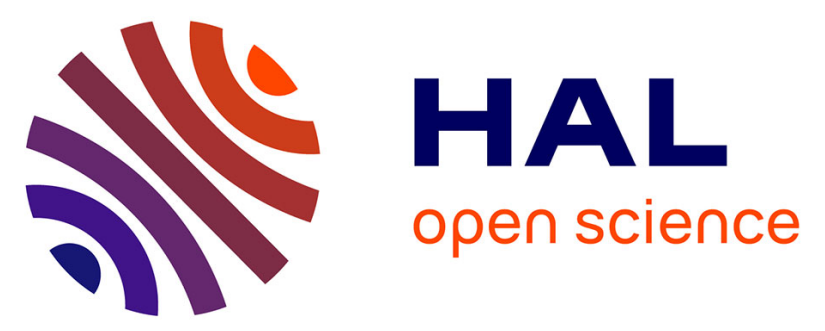

\title{
Long-term anti-tumour necrosis factor therapy reverses the progression of carotid intima-media thickness in female patients with active rheumatoid arthritis
}

A. Ferrante, A. R. Giardina, F. Ciccia, G. Parrinello, G. Licata, G. Avellone, E. Giardina, R. Impastato, Giovanni Triolo

\section{To cite this version:}

A. Ferrante, A. R. Giardina, F. Ciccia, G. Parrinello, G. Licata, et al.. Long-term anti-tumour necrosis factor therapy reverses the progression of carotid intima-media thickness in female patients with active rheumatoid arthritis. Rheumatology International, 2009, 30 (2), pp.193-198. 10.1007/s00296-0090935-2 . hal-00568287

\section{HAL Id: hal-00568287 \\ https://hal.science/hal-00568287}

Submitted on 23 Feb 2011

HAL is a multi-disciplinary open access archive for the deposit and dissemination of scientific research documents, whether they are published or not. The documents may come from teaching and research institutions in France or abroad, or from public or private research centers.
L'archive ouverte pluridisciplinaire HAL, est destinée au dépôt et à la diffusion de documents scientifiques de niveau recherche, publiés ou non, émanant des établissements d'enseignement et de recherche français ou étrangers, des laboratoires publics ou privés. 


\section{Full-text title}

Long-term anti-tumor necrosis factor therapy reverses the progression of carotid intima-media thickness in female patients with active rheumatoid arthritis.

From: A. Ferrante (1), AR. Giardina (1), F. Ciccia (1), (1), G. Parrinello (2), G. Licata (2), G. Avellone (2), E. Giardina (1), Impastato R (1) and G. Triolo (1)

Department of Internal Medicine, Divisions of Rheumatology (1) and Medicine (2), University of Palermo, Italy

Paper word count: 1801

Summary word count: 150

Running title: carotid intima-media thickness in anti-TNF treated rheumatoid arthritis

Key-word1 Rheumatoid arthritis; Key-word 2 TNF; Key-word 3 DMARDs; Key-word 4 atherosclerosis

Acknoledgments: This work was supported in part by a grant from Ministero della Ricerca e della Università of Italy (MIUR).

\section{Correspondence to:}

Professor Giovanni Triolo, Cattedra e Unità Operativa di Reumatologia, Policlinico Universitario, Piazza delle Cliniche 2, 90127 Palermo, Italy

e-mail g.triolo@unipa.it

Telephone +39+91 6552189; Fax +39+91 6552182 


\begin{abstract}
Objective: to evaluate the effect of TNF inhibition on carotid thickness over a two years period

Methods: 144 women with RA diagnosed according to ACR criteria, without clinical evidence of cardiac and/or vascular disease were enrolled and compared with 78 matched controls. All patients received methotrexate (15-20 mg weekly) for three months. Responders $(n=79)$ continued to be treat with methotrexate, non responders $(n=40)$ moved to methotrexate plus a TNF alpha antagonist. Echosonographic studies of carotids were obtained before and after two-years follow-up.
\end{abstract}

Results: a significant decrease of ca-IMT was observed in anti-TNF-treated patients $(p<0.001)$; on the other hand no significant variation of ca-IMT was observed after two years in MTX-treated patients

Conclusions. Our study indicates that anti-TNF blocking agents but not methotrexate are capable to reduce IMT of carotid arteries in females RA patients in a two years follow-up. 


\section{INTRODUCTION}

Patients with rheumatoid arthritis (RA) are at high risk of developing coronary heart disease (CHD). There is evidence of increased carotid intima-media thickness (IMT) in young long-term RA patients receiving standard methotrexate (MTX) therapy (1) and of high rates of myocardial infarction in women affected by RA in the absence of overt clinical atherosclerosis (2-4). The accelerated atherosclerosis found in these patients is not easily explained by traditional risk factors, suggesting that a systemic inflammatory response in RA may play a role in atherogenesis and/or in accentuating established atherosclerotic risk factors (5). Clinical and experimental data support the hypothesis that an effective control of inflammation may be of benefit in reducing cardiovascular risk in patients with RA. Recent studies in fact demonstrate the occurrence of endothelial dysfunction even in young patients with RA and low grade of inflammation (6-8). Anti-TNFalpha treatment is capable to transiently improve endothelial function in RA and to reduce aortic stiffness to a level comparable to that of healthy individuals (9-11), directly implicating TNF- $\alpha$ as an important mediator of endothelial dysfunction in RA.

Conflicting data probably due to selection of patients, and duration of treatment were published on the effect of anti TNF therapy in reducing the risk of cardiovascular disease in patients with RA (11-15).

Aim of this study was to assess the role of long term therapy with standard (methotrexate) or anti-TNF therapy on the intima-media thickness (IMT) in no-overt atherosclerotic women with active rheumatoid arthritis.

\section{METHODS}

\section{Study populations and design}

The study was approved by the institutional review board of our medical centre and written informed consent was obtained from subjects enrolled. One hundred-forty-four female patients with documented RA, diagnosed according to the American College of Rheumatology criteria for RA (16), were consecutively selected from the outpatient programme of the Academic Rheumatology Unit of the Palermo University. Patients had to be age $\geq 18$ years, be methotrexate (MTX) naïve and to have active disease with ESR > $28 \mathrm{~mm} 1 \mathrm{~h}$ and Disease Activity Score [DAS] > 2.4. Exclusion criteria included previous treatment with DMARDs other than antimalarials and evidence of atherosclerosis, cardiac disease, hypertension, diabetes mellitus assessed by history, physical examination and standard 12-lead ECG. Patients were compared with 78 healthy matched control subjects. All patients were checked for number of tender and swollen joints at 
baseline and every 3 months for two consecutive years. Patient's global assessment, physician's global assessment, physical disability score and patient's assessment of pain were also evaluated. Disease activity was calculated by a modified version of the disease activity score (17). Functional capacity was measured by the Health Assessment Questionnaire (HAQ) (18).

Patients were initially assigned to receive MTX administered orally or by intramuscolar weekly injection with a dosage of 10-20 mg. All the patients received folate supplementation. After three months therapy, non responders received in addition TNF-alpha blocking agents. In the last group of patients 20 were treated with infliximab (3 mg/Kg at week $0,2,6$ and then every 6-8 weeks), 15 with etanercept (25 mg twice weekly) and 5 with adalimumab (40 mg every other week) Assumption of low dose of steroids (prednisone $\leq$ $10 \mathrm{mg} / \mathrm{die}$ ) was also permitted.

\section{Carotid Ultrasonography}

The study was performed using an Hewlett Logic 500 Pro series General Electric ultrasound imaging system with an $10 \mathrm{MHz}$ electric linear transducer. All study partecipants underwent carotid ultrasonography, which was performed by the same experienced research sonographer. A single interpreter, who was blinded to the identity of the study partecipants, interpreted the results. Patients were studied in the supine position with slight hyperextension of the neck. Both extracranial carotid arterial systems were scanned in multiple planes using high resolution B-mode ultrasound. Plaque was defined either as a distinct protrusion of $>1.5 \mathrm{~mm}$ into the vessel lumen or as definite echogenicity with a posterior echogenic shadow. IMT was measured from end-diastolic (minimun dimension) M-mode images of the far wall of the distal common carotid artery (CCA). Mean values of right and left carotid IMT (ca-IMT) are presented. The reproducibility of the IMT measurements was evaluated in 10 subjects within ten days of the first examination. The correlation coefficient for IMT was 0.96 .

\section{Laboratory Assessment}

Baseline laboratory assessment, included routine chemistries, serum rheumatoid factor and anti-cyclic citrullinated peptide level. Lipid profile and inflammation pointers (ESR, CRP and fibrinogen) determination were performed at baseline and then every 3 months for two years. The erythrocyte sedimentation rate (ESR) was measured using the Westergren technique, and the C-reactive protein (CRP) by nephelometry. Total cholesterol, triglyceride, and high-density lipoprotein cholesterol levels were determined by the enzymatic method. Low-density lipoprotein (LDL) cholesterol levels were calculated by the formula of Friedewald and co-workers (19) which provides reliable values up to a TG concentration of $8.0 \mathrm{mmol} / \mathrm{l}$.

\section{Statistical analysis}

The results were compared by the paired and unpaired Student's t-test.

\section{RESULTS}

During the recruitment period 144 women affected by RA were enrolled. Clinical and laboratory characteristics of the study participants (RA patients and controls) are summarized in Table 1. There was no 
significant difference in these variables between RA patients and controls. Twenty-five patients were excluded from the study because of the absence of informed consent in 19, and the presence of carotid plaque in 6 . At the beginning of observation ca-IMT was $0.68 \pm 0.08$ (SD) $\mathrm{mm}$ in control subjects and $0.73 \pm$ 0.09 in patients with RA ( $<$ ) (figure 1). All patients were initially treated with methotrexate and low dose steroids. After three months 79 (responders) continued methotrexate for all the period of observation (group A); 40 patients started an anti-TNF agents (group B, not reponders to MTX alone). No significant difference was present in the demographic, clinical, and laboratory data in the two groups at baseline (table 2). A significant reduction from baseline of all clinical (DAS44, HAQ) and laboratory (CRP, Fibrinogen) parameters was reached after two years in both groups of patients (table 3). An increase in HDL cholesterol was observed in anti-TNF treated patients $(48.06 \pm 7.8$ vs $51.6 \pm 7.6 ; \mathrm{p}<0.05)$ (table 3$)$. Ca-IMT was $0.68 \pm 0.08$ (SD) $\mathrm{mm}$ in control subjects. A level $>0.76$ (mean $+1 \mathrm{SD}, 95$ percentile) was considered abnormal. ca-IMT was $0.722 \pm 0.099$ in group A and $0.737 \pm 0.104 \mathrm{~mm}$ in group B. Levels in both groups of patients were significantly higher than in controls $(p<0.01)$ (fig. 1). Fourteen patients in group A and 15 in group B had abnormal levels. No significant variation of ca-IMT was observed after two years in MTX-treated patients $(0.717 \pm 0.091$, NS) (fig. 2). On the other hand a significant decrease was observed in TNF-treated patients $(0.625 \pm 0.094$, p<0.001) (fig. 3).

\section{DISCUSSION}

Considerable evidence indicates that patients with rheumatoid arthritis (RA) are at greater risk of developing subclinical atherosclerosis and subsequently coronary heart disease (2-5). Although mechanisms involved are not clear, endothelial dysfunction, mediated by systemic inflammation seems to play a major role. Recent studies using "direct" measures of vascular function, such as pulse-wave analysis and flow-mediated vasodilatation confirmed the occurrence of significant endothelial dysfunction in long-term RA patients that correlates with markers of systemic inflammation $(20,21)$. Moreover untreated patients with RA have a less favourable atherogenic index mainly characterised by a decreased total cholesterol and relatively lower highdensity lipoprotein cholesterol (HDLc) levels, suggesting a close relationship between inflammation and dyslipidaemia (22). Endothelial cell activation has been hypothesized to link RA with an early initiation of atherosclerosis (23). TNF may mediate endothelial dysfunction both directly and indirectly (23). In addition TNF has been demonstrated to directly interfere with the metabolic pathways of triglycerides and cholesterol (24), and therefore the persistence of these modified lipids in the circulation may promote the development of atherosclerotic lesions. Anti-TNF therapy is expecting to reduce the risk of cardiovascular disease in RA. Anti-TNF treatment is in fact able to transiently improve endothelial function in RA, to reduce aortic stiffness to a level comparable to that of healthy individuals (9-11), directly implicating this cytokine as a mediator of endothelial dysfunction in RA, and to induce a modest, but sustained, increase in serum HDL-C levels, which may have in turn a favourable effect in reducing the cardiovascular risk in these patients (25). All together these data suggest that an effective control of inflammation may be of benefit in reducing cardiovascular risk in these patients. 
ca-IMT measurements are widely used in observational studies to evaluate determinants and consequences of atherosclerosis (26-29). Several studies have shown that increased ca-IMT confers risk of future coronary heart disease and stroke. Therefore, it has been suggested that measurements of carotid IMT may be used to identify high-risk subjects (30). ca-IMT measurements are currently used in randomized controlled trials as a surrogate end point for cardiovascular morbidity and mortality on the premise that change in c-IMT reflects change in risk of cardiovascular disease. The main advantage of using ca-IMT is the considerable reduction in sample size and possibly in duration of follow-up (29). Data from 13 published RCTs that use ca-IMT progression as an outcome showed that overall weighed rate of change in mean common ca-IMT was 0.0147 $\mathrm{mm} / \mathrm{y}$ (95\% CI, 0.0122 to 0.0173 ), with a median SD of 0.053 (29). Recently has been demonstrated that the rate at which the IMT increased per unit of age steepened in proportion to the RA duration, from 0.154 $\mathrm{mm} / 10$ years among patients with RA for 7 years or less, to $0.295 \mathrm{~mm} / 10$ years among patients with RA for 20 years or more (31).

According to our knowledge this is the first prospective study that compare two long-term treatments that include methotrexate and TNF blocking agents, to evaluate the effect of therapy on the progression of subclinical atherosclerosis in patients with rheumatoid arthritis. Indeed more recently, Gonzalez-Juanatey and co-workers (15) demonstrated the progression of subclinical atherosclerosis in a very little series of patients with RA and severe disease, despite periodic treatment with infliximab. However, this observational study included a limited number of patients with a longer duration of disease (15.4 years in average) and a older age at study onset (> 50 years). To minimize the influence of confounding variables associated with increased IMT, such as age, sex and duration and severity of disease, we selected relatively homogeneous groups including only women with age $<55$ years without a history of atherosclerosis. Although significant improvements were seen in measures of disease activity, CRP and fibrinogen levels with both type of treatments, anti-TNF blocking agents but not methotrexate alone was capable to reduce IMT of carotid arteries of female RA patients in a two-year follow up.

In conclusion, our study indicates that anti-TNF blocking agents but not methotrexate is capable to reduce IMT of carotid arteries of females RA patients in a two years follow-up. This effect may be due to the blocking of a cytokine directly involved in the pathogenesis of atherosclerosis

\section{REFERENCES}

1. Gonzalez-Juanatey C, Llorca J, Testa A, Revuelta J, Garcia-Porrua C, Gonzalez-Gay MA (2003) Increased prevalence of severe subclinical atherosclerotic findings in long-term treated rheumatoid arthritis patients without clinical evident atherosclerotic disease. Medicine (Baltimore) 82:407-413 Medline. doi:10.1097/01.md.0000101572.76273.60

2. Solomon DH, Karlson EW, Rimm EB, Cannuscio CC, Mandl LA, Manson JE, et al (2003) Cardiovascular morbidity and mortality in women diagnosed with rheumatoid arthritis. Circulation 107:1303-1307 Medline. doi:10.1161/01.CIR.0000054612.26458.B2 
3. Fischer LM, Schlienger RG, Matter C, Jick H, Meier CR (2004) Effect of rheumatoid arthritis or systemic lupus erythematosus on the risk of first-time acute myocardial infarction. Am J Cardiol 93:198-200 Medline. doi:10.1016/j.amjcard.2003.09.037

4. del Rincòn I, Williams K, Stern MP, Freeman GL, Escalante A (2001) High incidence of cardiovascular events in a rheumatoid arthritis cohort not explained by traditional risk factors. Arthritis Rheum 44:2737-2745 Medline. doi:10.1002/1529-0131(200112)44:12<2737::AIDART460>3.0.CO;2-\#

5. Van Doornum S, McColl G, Wicks IP (2002) Accelerated atherosclerosis: an extraarticular feature of rheumatoid arthritis? Arthritis Rheum 46:862-873 Medline. doi:10.1002/art.10089

6. Hansel S, Lassig G, Pistrach F, Passauer J (2003) Endothelial dysfunction in young patients patients with long-term rheumatoid arthritis and low disease activity. Artherosclerosis 170:177180. doi:10.1016/S0021-9150(03)00281-8

7. Vaudo G, Marchesi S, Gerli R, Allegrucci R, Giordano A, Siepi D, et al (2004) Endothelial dysfunction in young patients patients with long-term rheumatoid arthritis and low disease activity. Ann Rheum Dis 63:31-35 Medline. doi:10.1136/ard.2003.007740

8. Sattar N, Mc Carey DW, Capell H, McInnes IB (2003) Explaining how high grade systemic inflammation accelerates vascular risk in rheumatoid arthritis. Circulation 108:2957-2963 Medline. doi:10.1161/01.CIR.0000099844.31524.05

9. Hurlimann D, Forster A, Noll G, Enseleit F, Chenevard R, Distler O, et al (2002) Anti-tumor necrosis factor-alpha treatment improves endothelial function in patients with rheumatoid arthritis. Circulation 106:2184-2187 Medline. doi:10.1161/01.CIR.0000037521.71373.44

10. Gonzalez-Juanatey C, Testa A, Garcia-Castelo A, Garcia-Porrua C, Llorca J, Gonzalez-Gay MA (2004) Active but transient improvement of endothelial function in rheumatoid arthritis patients undergoing long-term treatment with anti-tumor necrosis factor - antibody. Arthritis Rheum 51:447-450 Medline. doi:10.1002/art.20407

11. Maki-Petaja KM, Hall FC, Booth AD, Wallace SM, Yasmin, Bearcroft PW et al (2006) Rheumatoid arthritis is associated with increased aortic pulse-wave velocity, which is reduced by anti-tumor necrosis factor-alpha therapy. Circulation 114(11):1185-1192 Medline. doi:10.1161/CIRCULATIONAHA.105.601641

12. Van Doornum S, McColl G, Wicks IP (2005) Tumour necrosis factor antagonists improve disease activity but not arterial stiffness in rheumatoid arthritis. Rheumatology (Oxford) 44:1428-1432 Medline. doi:10.1093/rheumatology/kei033 
13. Irace C, Mancuso G, Fiaschi E, et al (2004) Effect of anti TNFalpha therapy on arterial diameter and wall shear stress and HDL cholesterol. Atherosclerosis 177:113-118 Medline. doi:10.1016/j.atherosclerosis.2004.04.031

14. van Halm VP, Nurmohamed MT, Twisk JW, Dijkmans BA, Voskuyl AE (2006) Diseasemodifying antirheumatic drugs are associated with a reduced risk for cardiovascular disease in patients with rheumatoid arthritis: a case control study. Arthritis Res Ther 8(5):R151 Medline. doi:10.1186/ar2045

15. Gonzalez-Juanatey C, Llorca J, Garcia-Porrua C, Martin J, Gonzalez-Gay MA (2006) Effect of anti-tumor necrosis factor a therapy on the progression of subclinical atherosclerosis in severe rheumatoid arthritis. Arthritis Rheum 55:150-153 Medline. doi:10.1002/art.21707

16. Arnett FC, Edworthy SM, Bloch DA, McShane DJ, Fries JF, Cooper NS, et al (1988) The american Rheumatism Association 1987 revised criteria for the classification of rheumatoid arthritis. Arthritis Rheum 31:315-324 Medline. doi:10.1002/art.1780310302

17. Prevoo ML, van 't Hof MA, Kuper HH, van Leeuwen MA, van de Putte LB, van Riel PL (1995) Modified disease activity scores that include twenty-eight-joint counts: development and validation in a prospective longitudinal study of patients with rheumatoid arthritis. Arthritis Rheum 38:44-48 Medline. doi:10.1002/art.1780380107

18. Fries JF, Spitz P, Kraines RG, Holman HR (1980) Measurement of patients outcome in arthritis. Arthritis Rheum 23:137-145 Medline. doi:10.1002/art.1780230202

19. Friedwal WT, Levy RI, Friedckson DS (1972) Estimation of the concentration of low density lipoprotein in plasma, without use of preparative ultracentrifuge. Clin Chem 18:499-502 Medline.

20. Van Doornum S, McColl G, Jenkins A, Green DJ, et al (2003) Screening for atherosclerosis in patients with rheumatoid arthritis: comparison of two in vivo tests of vascular function. Arthritis Rheum 48:72-80 Medline. doi:10.1002/art.10735

21. Mäki-Petäjä KM, Hall FC, Booth AD, Wallace SML, et al (2006) Rheumatoid arthritis is associated with increased aortic pulse wave velocity, which is reduced by anti-tumor necrosis factor-alpha therapy. Circulation 114:1185-1192 Medline. doi:10.1161/CIRCULATIONAHA.105.601641

22. Park YB, Lee SK, Lee WK, Suh CH, et al (1999) Lipid profiles in untreated patients with rheumatoid arthritis. J Rheumatol 26:1701-1704 Medline. 
23. Sattar N, McCarey DW, Capell H, et al (2003) Explaining how "high-grade" systemic inflammation accelerates vascular risk in rheumatoid arthritis. Circulation 108:2957-2963 Medline. doi:10.1161/01.CIR.0000099844.31524.05

24. Grunfeld C, Feingold KR (1991) Tumour necrosis factor, cytokines and the hyperlipidemia of infection. Trends Endocrinol Metab 2:213-219 Medline. doi:10.1016/1043-2760(91)90027-K

25. Spanakis E, Sidiropoulos P, Papadakis J, Ganotakis E, et al (2006) Modest but sustained increase of serum high density lipoprotein cholesterol levels in patients with inflammatory arthritides treated with infliximab. J Rheumatol 33:2440-2446 Medline.

26. Geroulakos G, O’Gorman DJ, Kalodiki E, Sheridan DJ, Nicolaides AN (1994) The carotid intima-media thickness as a marker of the presence of severe symptomatic coronary artery disease. Eur Heart J 15:781-785 Medline.

27. Tang R, Hennig M, Thomasson B, Scherz R, et al (2000) Baseline reproducibility of B-mode ultrasonic measurement of carotid artery intima-media thickness: the European Lacidipine Study on Atherosclerosis (ELSA). J Hypertens 18:197-201 Medline. doi:10.1097/00004872$\underline{200018020-00010}$

28. Salonen JT, Salonen R (1993) Ultrasound B-mode imaging in observational studies of atherosclerotic progression. Circulation 87:II56-II65 Medline.

29. Bots ML, Evans MA, Riley WA, Grobbee DE (2003) Carotid intima-media thickness measurements in intervention studies. Stroke 34:2985-2994 Medline.

doi:10.1161/01.STR.0000102044.27905.B5

30. Grobbee DE, Bots ML (1994) Carotid artery intima-media thickness as an indicator of generalized atherosclerosis. J Intern Med 236:567-573 Medline.

31. Del Rincon I, O'leary DH, Freeman GL, Escalante A (2007) Acceleration of atherosclerosis during the course of rheumatoid arthritis. Atherosclerosis 195:354-360 Medline. doi:10.1016/j.atherosclerosis.2006.09.027 
Table 1. Characteristics of RA patients and healthy controls

\begin{tabular}{lccc}
\hline & $\begin{array}{c}\text { RA } \\
(\mathbf{N}=144)\end{array}$ & $\begin{array}{c}\text { Controls } \\
(\mathbf{N}=78)\end{array}$ & P \\
\hline Age, mean \pm DS & $45.3 \pm 8.2$ & $43.4 \pm 7.8$ & NS \\
BMl, mean \pm DS $\left(\mathrm{Kg} / \mathrm{m}^{2}\right)$ & $23.07 \pm 4.33$ & $22.9 \pm 3.6$ & $\mathrm{NS}$ \\
Smokers $/$ not smokers & $20 / 124$ & $17 / 52$ & $\mathrm{NS}$ \\
Cholesterol, mean \pm SD $(\mathrm{mg} / \mathrm{dl})$ & $204.9 \pm 34.3$ & $203.8 \pm 32.2$ & $\mathrm{NS}$ \\
Triglicerids, mean $\pm \mathrm{SD}, \mathrm{mg} / \mathrm{dl}$ & $107 \pm 41.1$ & $106.0 \pm 30.4$ & $\mathrm{NS}$ \\
HDL-C $(\mathrm{mg} / \mathrm{dl})$ & $48,3 \pm 8.0$ & $49,2 \pm 9,3$ & $\mathrm{NS}$ \\
LDL-C $(\mathrm{mg} / \mathrm{dl})$ & $139.3 \pm 28.4$ & $134.5 \pm 25.1$ & $\mathrm{NS}$
\end{tabular}




\begin{tabular}{lccc} 
LDL-C/HDL-C & $2.9 \pm 0.8$ & $2.8 \pm 0.7$ & NS \\
Apo A1 & $134.7 \pm 30.9$ & $138.3 \pm 30.1$ & NS \\
Apo B & $105.6 \pm 23.8$ & $103.5 \pm 23.0$ & NS \\
\hline
\end{tabular}

Table 2. Characteristics of the two groups of patients

\begin{tabular}{lccc}
\hline & Group B & Group A & P \\
& Anti-TNF- $\alpha$ & MTX & \\
& $(\mathrm{N}=40)$ & $(\mathrm{N}=79)$ & \\
\hline Duration of RA (months), mean \pm SD & $33.55 \pm 13.39$ & $32.89 \pm 14.28$ & NS \\
Age, mean \pm DS & $43.62 \pm 8.5$ & $46.9 \pm 7.86$ & NS \\
DAS, mean \pm SD & $4.62 \pm 0.92$ & $4.57 \pm 1$ & NS \\
Erosions, \% & $65 \%$ & $66 \%$ & NS \\
ESR (mm 1h), median & 36 & 32 & NS \\
CRP mg/l, mean \pm SD & $4,71 \pm 0.93$ & $4,54 \pm 1,69$ & NS \\
Fibrinogen mg/dl, mean \pm SD & $487 \pm 88$ & $486 \pm 85$ & NS \\
HAQ, mean \pm SD & $2.63 \pm 0.43$ & $2.6 \pm 0.46$ & NS \\
RF,$+ \%$ & 79 & 76 & NS \\
Anti-CCP+, \% & 65 & 66 & NS \\
Cumulative dose of prednisone, grams & $3.72 \pm 0.75$ & $3.68 \pm 0.25$ & NS \\
\hline
\end{tabular}

Table 3 measures of activity and of lipid levels in the two groups of therapy

\begin{tabular}{lcccc}
\hline & \multicolumn{2}{c}{ Group A (Methotrexate) } & \multicolumn{2}{c}{ Group B (anti-TNF) } \\
\hline (mean \pm SD) & Baseline & After 2 years & Baseline & After 2 years \\
\cline { 2 - 5 } DAS & $4.57 \pm 1$ & $2.39 \pm 0,5^{*}$ & $4.62 \pm 0.92$ & $2.14 \pm 0,32^{*}$ \\
CRP & $4.54 \pm 1.69$ & $2.48 \pm 1.12^{*}$ & $4.71 \pm 0.93$ & $2.37 \pm 0.79^{*}$ \\
Fibrinogen & $486 \pm 85$ & $353 \pm 88^{*}$ & $487 \pm 88$ & $326 \pm 78^{*}$ \\
Cholesterol & $203 \pm 31.5$ & $205 \pm 30.7$ & $206 \pm 37.9$ & $203.5 \pm 36.46$ \\
Triglicerid & $109.7 \pm 47.4$ & $111.5 \pm 39.9$ & $106.7 \pm 35.6$ & $108.6 \pm 30$
\end{tabular}




\begin{tabular}{lcccc} 
HDL-C & $48.5 \pm 8.5$ & $47.4 \pm 7.1$ & $48.06 \pm 7.8^{*}$ & $51.6 \pm 7.6^{*}$ \\
$\mathrm{HAQ}$ & $2.63 \pm 0,43$ & $2.13 \pm 0,47$ & $2.6 \pm 0.46$ & $1.77 \pm 0,29$ \\
\hline${ }^{*} \mathrm{p}<0.05$ & & & \\
\hline
\end{tabular}

Fig. 1 


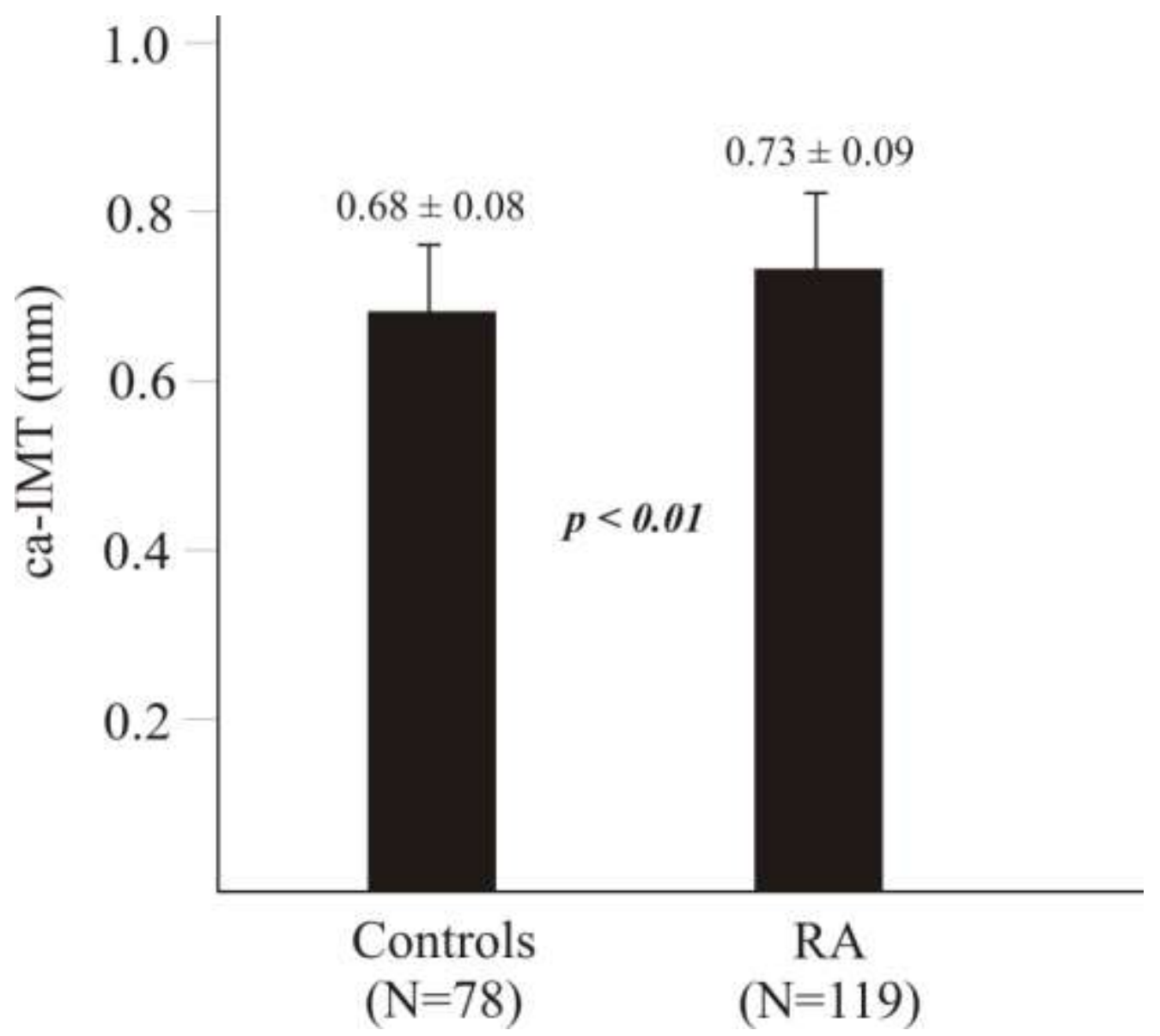

Fig. 2 


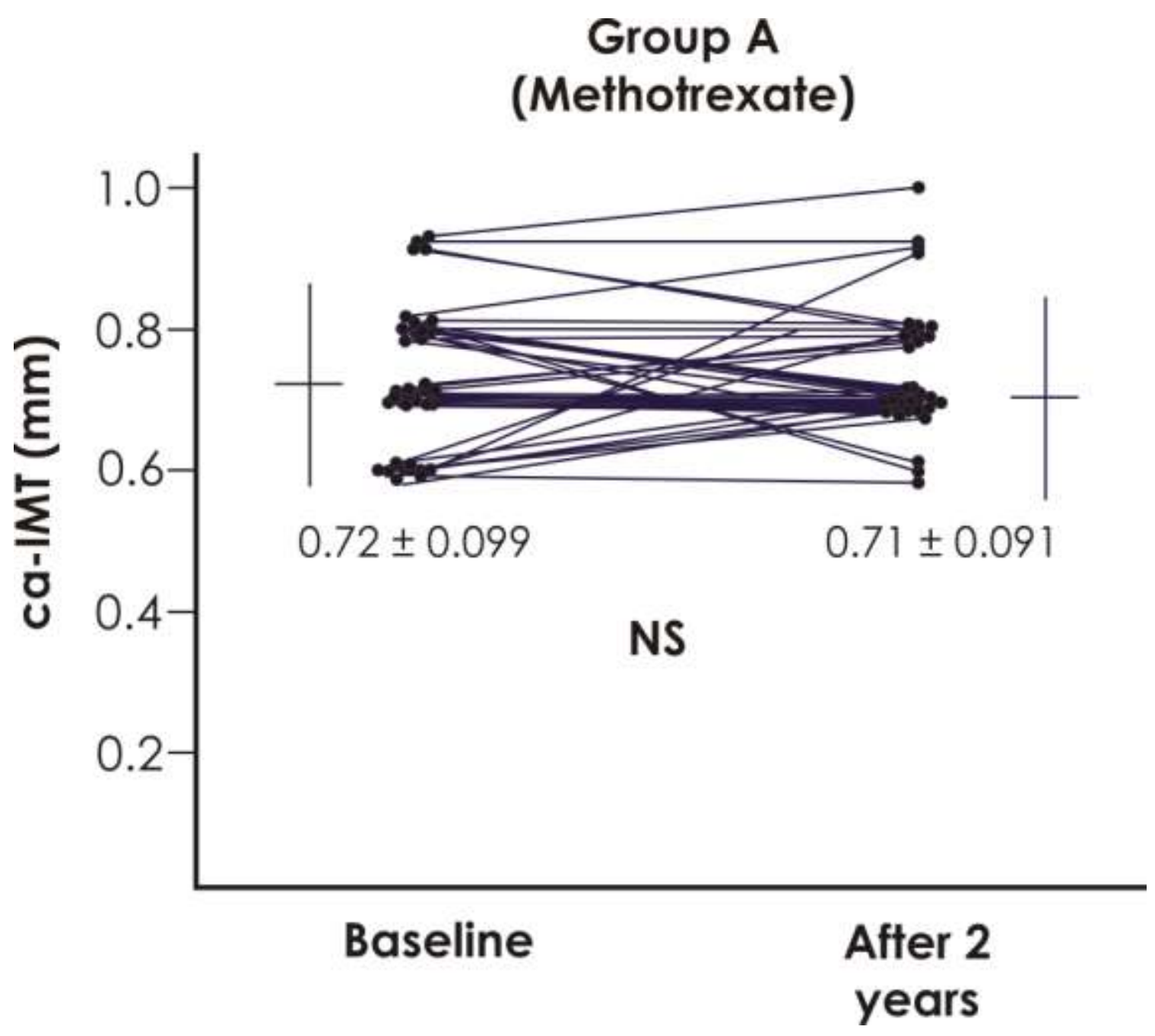

Fig. 3 


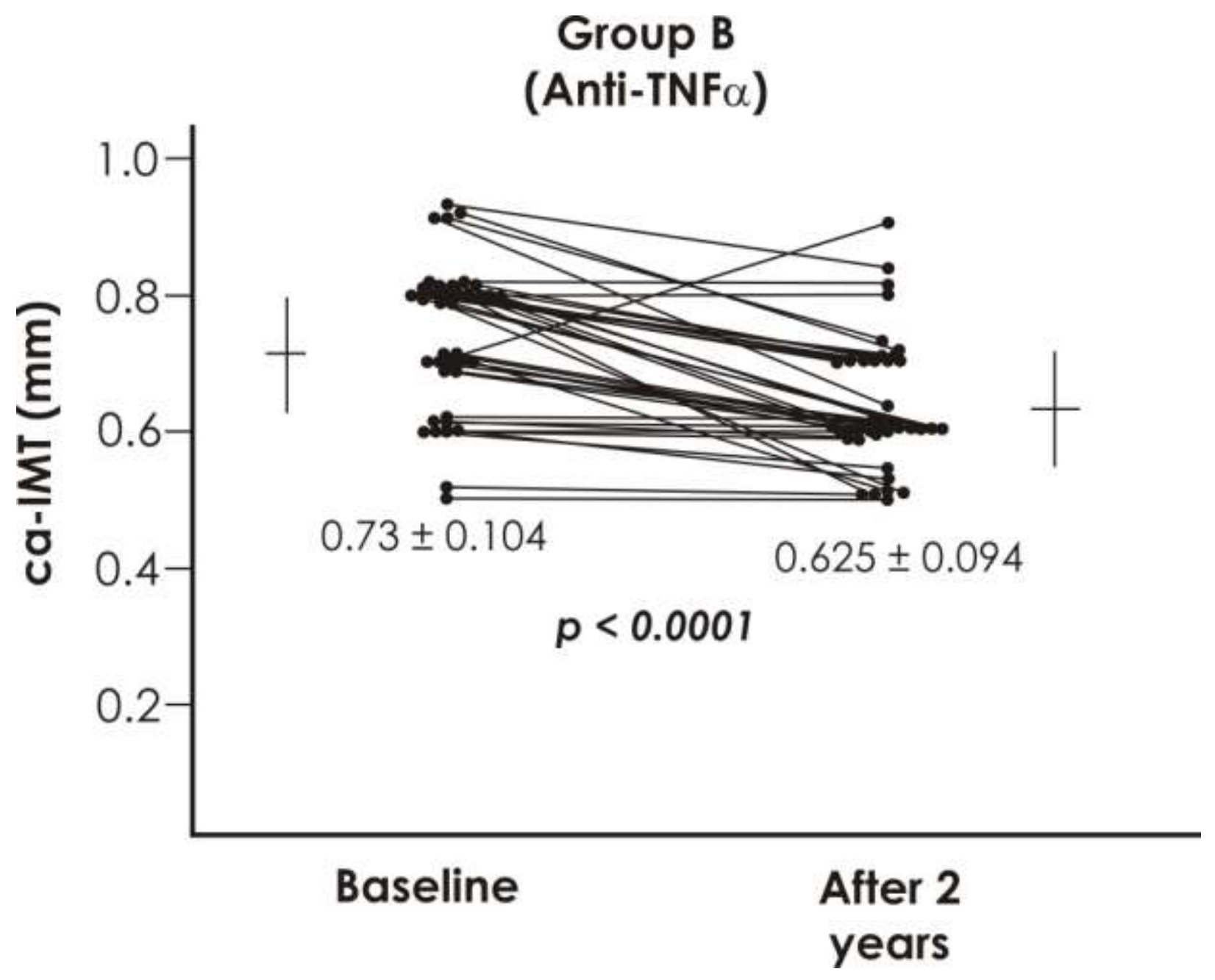




\section{Legend to figures}

Figure 1. ca-IMT in patients with RA vs healthy controls

Figure 2. ca-IMT in patients with RA treated with methotrexate at baseline and after 2 years

Figure 3. ca-IMT in patients with RA treated with anti-TNF $\alpha$ plus methotrexate at baseline and after 2 years 